\title{
Dietary intake and main sources of plant lignans in five European countries
}

Inge Tetens'**, Aida Turrini², Heli Tapanainen ${ }^{3}$, Tue Christensen', Johanna W. Lampe ${ }^{4}$, Sisse Fagt', Niclas Håkansson ${ }^{5}$, Annamari Lundquist', Jesper Hallund', Liisa M. Valsta ${ }^{3,6}$ and The Phytohealth WPI working group

\author{
'Division of Nutrition, National Food Institute, Technical University of Denmark, Søborg, DK, Denmark; ${ }^{2}$ National \\ Institute for Research on Food and Nutrition, Rome, IT, Italy; ${ }^{3}$ National Institute for Health and Welfare, Helsinki, Fl, \\ Finland; ${ }^{4}$ Fred Hutchinson Cancer Research Centre, Cancer Prevention Program, Seattle, WA, USA; ${ }^{5}$ Institute of \\ Environmental Medicine, Karolinska Institute, Stockholm, SE, Sweden; ${ }^{6}$ European Food Safety Authority, Parma, IT, Italy
}

Abstract

Background: Dietary intakes of plant lignans have been hypothesized to be inversely associated with the risk of developing cardiovascular disease and cancer. Earlier studies were based on a Finnish lignan database (Fineli $\left.{ }^{\circledR}\right)$ with two lignan precursors, secoisolariciresinol (SECO) and matairesinol (MAT). More recently, a Dutch database, including SECO and MAT and the newly recognized lignan precursors lariciresinol (LARI) and pinoresinol (PINO), was compiled. The objective was to re-estimate and re-evaluate plant lignan intakes and to identify the main sources of plant lignans in five European countries using the Finnish and Dutch lignan databases, respectively.

Methods: Forty-two food groups known to contribute to the total lignan intake were selected and attributed a value for SECO and MAT from the Finnish lignan database (Fineli ${ }^{\circledR}$ ) or for SECO, MAT, LARI, and PINO from the Dutch database. Total intake of lignans was estimated from food consumption data for adult men and women (19-79 years) from Denmark, Finland, Italy, Sweden, United Kingdom, and the contribution of aggregated food groups calculated using the Dutch lignin database.

Results: Mean dietary lignan intakes estimated using the Dutch database ranged from 1 to $2 \mathrm{mg} /$ day, which was approximately four-fold higher than the intakes estimated from the Fineli ${ }^{\circledR}$ database. When LARI and PINO were included in the estimation of the total lignan intakes, cereals, grain products, vegetables, fruit and berries were the most important dietary sources of lignans.

Conclusion: Total lignin intake was approximately four-fold higher in the Dutch lignin database, which includes the lignin precursors LARI and PINO, compared to estimates based on the Finnish database based only on SECO and MAT. The main sources of lignans according to the Dutch database in the five countries studied were cereals and grain products, vegetables, fruit, berries, and beverages.

Keywords: lignan intake; secoisolariciresinol; matairesinol; lariciresinol; pinoresinol

Received: 2 October 2012; Revised: 8 April 2013; Accepted: 23 April 20I3; Published: II June 2013

$\mathrm{P}$ lant lignans are plant-derived diphenolic compounds that belong to the group of phytoestrogens that are structurally similar to 17 -estradiol. After ingestion, plant lignans are metabolized to the enterolignans enterodiol (END) and enterolactone (ENL) by colonic bacteria before they are absorbed $(1,2)$. END and ENL are detected in plasma within 8-10 h after intake of plant lignans (3), and their half-lives in plasma are approximately 5 and $13 \mathrm{~h}$, respectively $(4,5)$.
However, a substantial inter-individual variation has been detected in plasma concentrations and urinary excretion of enterolignans, partly due to the complex interaction between colonic environment and external and internal factors (6) which moreover, seems to be more dependent on the dietary lignan source than the absolute lignan intake (7). Reliable methods of exposure measurement are crucial for understanding the possible health benefits of plant lignans and the first step in this 
process is to establish comprehensive dietary databases to estimate plant lignan exposure in population-based studies (6).

Observational studies have examined the association between habitual intake of plant lignans - estimated from the intake of selected food items and their content of two major precursors of enterolignans secoisolariciresinol (SECO) and matairesinol (MAT) - and risk of developing lifestyle-related diseases, such as cardiovascular disease $(8,9)$, breast cancer $(10)$, and prostate cancer $(11)$. The metabolite responsible is ENL showing an inverse association with postmenopausal breast cancer risk (12) and mortality risk due to coronary heart disease, cardiovascular disease (13), and breast cancer (14) at high ENL serum levels. Furthermore, animal experiments on rats (15) and studies in vitro showed a breast cancer protective effect of END and ENL that is discussed to be imputable to their higher biological activity (16). Dietary lignan intake was also found to decrease the risk of adenocarcinoma of the esophagus and gastroesophageal junction on a case-control study (17).

As progress has been made in this area, a food database of Dutch plant foods was published (18) with data on the content of SECO and MAT, as well as two more recently identified precursors of mammalian lignans, lariciresinol (LARI) and pinoresinol (PINO) (19). Estimated dietary intakes of lignans in the Dutch diet based on the new food database of Dutch plant foods (20) suggest that plant lignan intakes are much higher than first reported (21-24) and that LARI and PINO contribute approximately $75 \%$ to the estimated intake of plant lignans in the Dutch diet with the primary food group sources of lignans being beverages, vegetables, nuts and seeds, bread and fruits (20). A few oilseeds, such as flaxseed and sesame seeds have a high content of plant lignans (18), but the intake of such foods is only used by a small proportion of the population and commonly, the amounts consumed are low (20).
In addition to the improved understanding of the importance of total lignan intakes, it has become clear that the contribution of selected food groups to the total plant lignan intake may be different than originally expected due to the contribution from LARI and PINO. Therefore, it is necessary to re-estimate and re-evaluate the total intake of plant lignans and contribution from different food groups to the total intakes in other European countries.

The main objective of this study is to estimate the total intake of plant lignans and identify the main food sources of plant lignans in different European countries by using a Finnish lignan database (Fineli $\left.{ }^{\circledR}\right)$ which includes two enterolignan precursors MAT and SECO and a Dutch lignan database which includes four enterolignan precursors SECO, MAT, LARI, and PINO.

\section{Methods}

The lignan intakes were calculated from 42 food groups that included plant foods and beverages known to be sources of lignans among European men and women. Each of the 42 food groups were given a lignan value for the content of the mammalian lignan precursors MAT, SECO, PINO, and LARI based on the lignan database of Dutch plant foods (18) or on only MAT and SECO based on the Fineli ${ }^{\circledR}$ database from Finland (24) as described in Appendix A. Both databases provide the Linnean binomial nomenclature for plants. The new lignan values for food groups were either weighted values or arithmetic means based on the food content of plant lignans available from commonly consumed food items best representing that food group. For example, in the case of Fineli ${ }^{\circledR}$-based values, the lignan content of whole grain rye flour contributed most to the food group 'rye', whereas the value for cabbages was the arithmetic mean of all available lignan values for different types of cabbages. In the case of food group values based on the Dutch database, the food group values were based on a

Table 1. Description of the food consumption data

\begin{tabular}{|c|c|c|c|c|c|}
\hline Country & Year & Dietary data level & $N$, age & Methodology used & Reference \\
\hline Denmark & $2000-2002$ & National dietary survey, data at individua. level & $\begin{array}{l}\text { F: I,307; M: I,I } 156 \\
25-64 \text { years }\end{array}$ & $\begin{array}{l}\text { 7-day pre-coded food } \\
\text { record }\end{array}$ & (25) \\
\hline Finland & 2002 & $\begin{array}{l}\text { National dietary survey (FINDIET), data at individual } \\
\text { level }\end{array}$ & $\begin{array}{l}\text { F: I,095; M: } 912 \\
25-64 \text { years }\end{array}$ & 48-h dietary recall & (26) \\
\hline Italy & $1994-1996$ & National dietary survey, data at individual level & $\begin{array}{l}\text { F: } 682 ; \text { M: } 586 \\
25-64 \text { years }\end{array}$ & $\begin{array}{l}\text { 7-day mixed survey } \\
\text { technique }\end{array}$ & (27) \\
\hline Sweden & $1987-1990$ & $\begin{array}{l}\text { Cohort studies (Swedish Mammography Cohort } \\
\text { (SMC) \& Cohort of Swedish Men (COSM), data at } \\
\text { group level }\end{array}$ & $\begin{array}{l}\mathrm{F}: 37,854 ; \mathrm{M}: \\
45,90645-79 \\
\text { years }\end{array}$ & $\begin{array}{l}\text { 96-item food frequency } \\
\text { questionnaire (FFQ) }\end{array}$ & (28) \\
\hline United Kingdom & $2000-2001$ & National dietary survey, data at individual level & $\begin{array}{l}\text { F: 958; M: } 766 \\
\text { 19-64 years }\end{array}$ & 7-day dietary record & (29) \\
\hline
\end{tabular}

$F=$ females; $M=$ males. 
single analyzed food item (e.g. value of strawberry for the group 'berries') or arithmetic means drawn from the analyzed values available in the database (e.g. mean of tofu and soy milk for the group 'soy products').

Food consumption data for men and women were available for Denmark, Finland, Italy, Sweden, and the United Kingdom. The data included individual data from national dietary surveys (DK, FI, IT, UK) and from cohort studies in Sweden. An overview of the studies is presented in Table 1. All analyses were performed by using SPSS statistical software package (version 12, Chicago). The non-parametric Kruskal-Wallis ranked test was used to test the differences in the distribution of the total lignan intakes between Denmark, Finland, and Italy. Lignan intakes and source estimates were calculated by Microsoft Office Excel (2003).

\section{Results}

The mean lignan intake estimated using the Dutch lignan database with the four lignan precursors SECO, MAT, LARI, and PINO was lowest among Finnish women $(1,036 \mu \mathrm{g} /$ day $)$ and highest among Swedish men $(1,947$ $\mu \mathrm{g} / \mathrm{day}$ ) (Table 2). It is noticeable that the SECO and MAT figures are systematically smaller when calculated using the Dutch data set compared with the Finnish database. SECO contributed between 11 and $22 \%$ to the lignan intake, MAT between 1 and 3\%, LARI between 41 and $45 \%$ and PINO between 32 and $44 \%$. The total lignan intake was approximately four times higher when the estimates were calculated using the Dutch lignan database compared to the results based on the Finnish lignan database (Fineli ${ }^{\circledR}$ database). According to the latter estimates, the mean lignan intake was lowest among Italian women $(272 \mu \mathrm{g} /$ day $)$ and highest among Danish women $(439 \mu \mathrm{g} /$ day $)$ and SECO contributed between 81 and $94 \%$ to the lignan intake and MAT between 6 and $19 \%$.

The frequency distribution of the estimated total lignan intake among Danish, Finnish, and Italian adults using the Dutch and Finnish (Fineli ${ }^{\circledR}$ ) lignan databases is shown in Fig. 1. The mean lignan intake between countries estimated using the Dutch lignan database of plant foods ranged from $404 \mu \mathrm{g} / \mathrm{day}$ among Finnish adults to $569 \mu \mathrm{g} /$ day among Italian adults and was slightly skewed toward higher values. The mean lignan intake estimated using the Finnish (Fineli ${ }^{\circledR}$ ) lignan database within one country ranged from 91 to $2,335 \mu \mathrm{g} /$ day among Italian adults and was strongly skewed toward higher values. Significant differences were found between the three countries in the total lignan intakes estimated using both the Dutch database $(P<0.001)$ and the Finnish $\left(\right.$ Fineli $\left.{ }^{\circledR}\right)$ lignan databases $(P<0.001)$ (data not shown).

Table 2. Lignan intakes (g/day) from five European countries calculated using the Dutch and the Finnish (Fineli ${ }^{\circledR}$ ) lignan database (mean values)

\begin{tabular}{|c|c|c|c|c|c|c|c|c|}
\hline \multirow{3}{*}{ Country } & \multicolumn{5}{|c|}{ Dutch lignan database } & \multicolumn{3}{|c|}{ Finnish (Fineli ${ }^{\circledR}$ ) lignan database } \\
\hline & \multicolumn{5}{|c|}{ Estimated lignan intake (g/day) } & \multicolumn{3}{|c|}{ Estimated lignan intake (g/day) } \\
\hline & SECO & MAT & LARI & PINO & Total & SECO & MAT & Total \\
\hline \multicolumn{9}{|l|}{ Denmark } \\
\hline All $(n=2,463)$ & 314 & 41 & 630 & 473 & 1,459 & 375 & 57 & 432 \\
\hline Female $(n=1,307)$ & 314 & 43 & $64 I$ & 486 & $\mathrm{I}, 484$ & 380 & 59 & 439 \\
\hline Male $(n=1,156)$ & 315 & 38 & 618 & 459 & 1,430 & 370 & 54 & 424 \\
\hline \multicolumn{9}{|l|}{ Finland } \\
\hline All $(n=2,007)$ & 188 & 23 & 469 & 401 & $|, 08|$ & 245 & 40 & 285 \\
\hline Female $(n=1,095)$ & 176 & 21 & 455 & 384 & 1,036 & 245 & 34 & 279 \\
\hline Male $(n=9 \mid 2)$ & 202 & 26 & 486 & 422 & 1136 & 246 & 48 & 293 \\
\hline \multicolumn{9}{|l|}{ Italy } \\
\hline All $(n=1,268)$ & 143 & 11 & 500 & 467 & 1,120 & 290 & 19 & 309 \\
\hline Female $(n=682)$ & 125 & 9 & 477 & 452 & 1,062 & 257 & 16 & 272 \\
\hline Male $(n=586)$ & 165 & 14 & 527 & 484 & 1,188 & 329 & 23 & 351 \\
\hline \multicolumn{9}{|l|}{ Sweden } \\
\hline All $(n=83,760)$ & 224 & 37 & 735 & 777 & $\mathrm{I}, 773$ & 318 & 60 & 377 \\
\hline Female $(n=37,854)$ & 203 & 28 & 657 & 675 & 1,563 & 300 & 39 & 339 \\
\hline Male $(n=45,906)$ & 242 & 45 & 799 & 861 & 1,947 & 332 & 77 & 409 \\
\hline \multicolumn{9}{|l|}{ United Kingdom } \\
\hline All $(n=1,724)$ & 205 & 19 & 535 & 480 & 1,239 & 267 & 17 & 285 \\
\hline Female $(n=89 \mid)$ & 197 & 19 & 507 & 450 & 1,173 & 265 & 17 & 282 \\
\hline Male $(n=833)$ & 214 & 19 & 570 & 518 & 1,321 & 270 & 18 & 288 \\
\hline
\end{tabular}



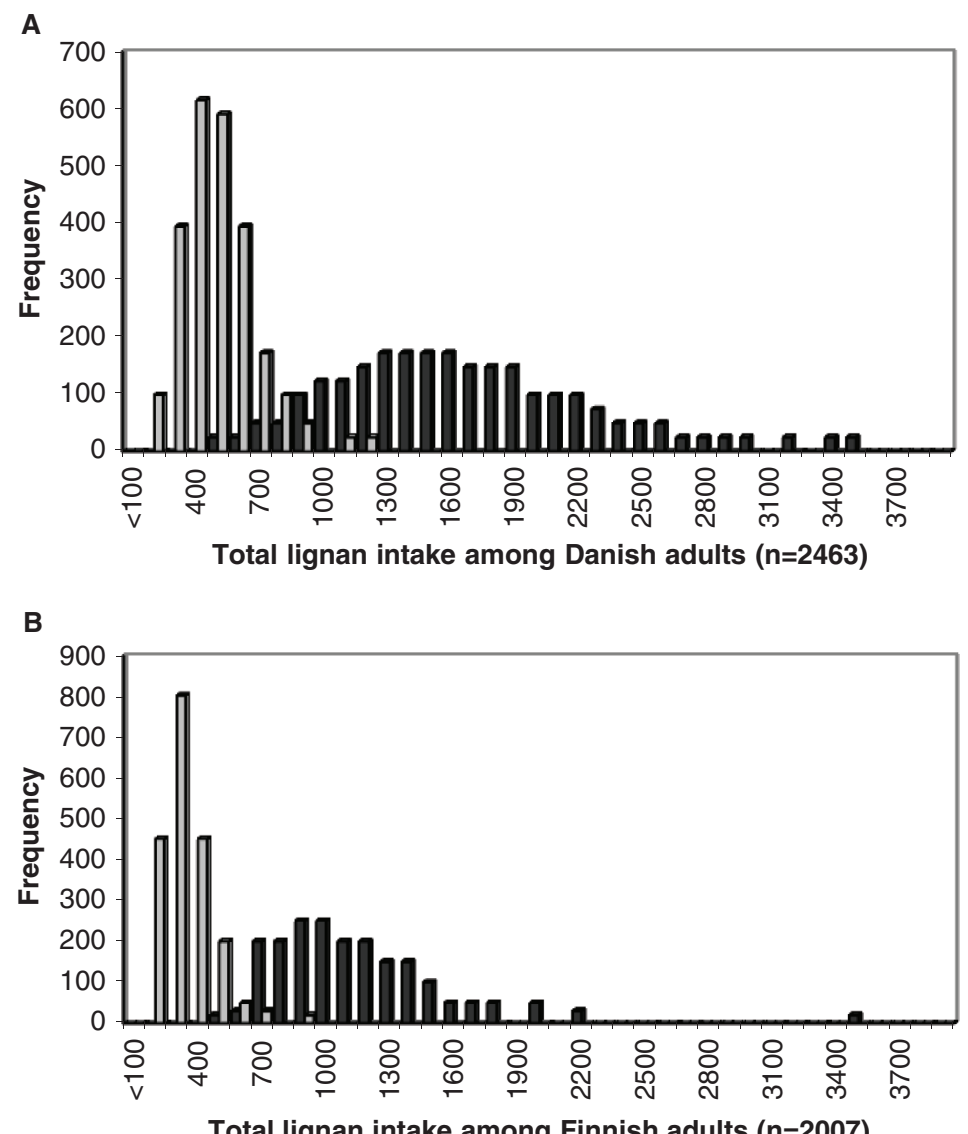

C

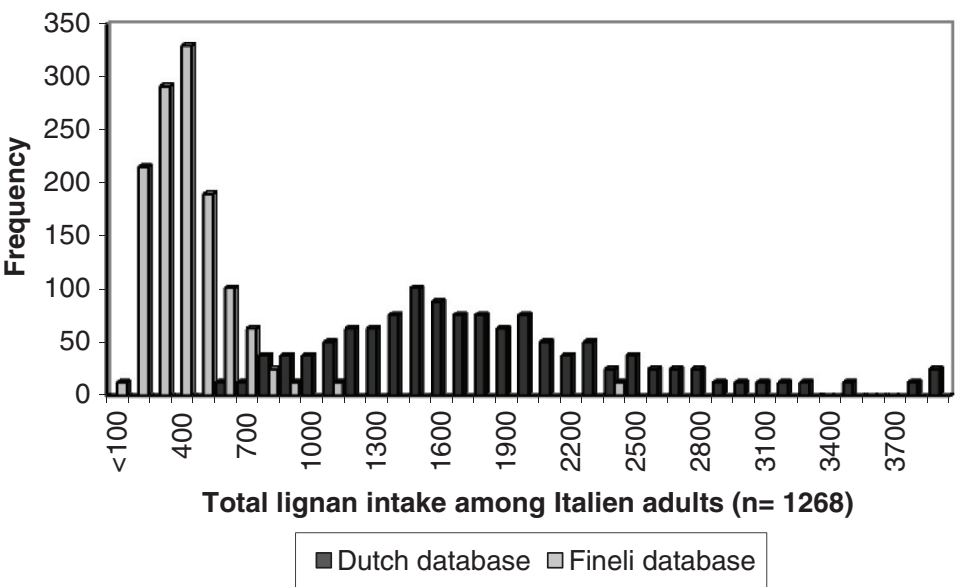

Fig. 1. Distribution of estimated lignan intake ( $\mu \mathrm{g} /$ day) among adults in Denmark (A), Finland (B), and Italy (C) calculated using the Dutch and the Finnish $\left(\right.$ Fineli $\left.^{\circledR}\right)$ lignan database.

The main food groups and food items contributing to the lignan intake estimated using the Dutch lignan database are shown in Table 3. Only food groups and food items, that contributed more than $5 \%$ to total lignan intake, have been included in the table. The most important food groups were 'cereals and grain products', 'vegetables', and 'fruit and berries'. Cereals and grain products contributed $15-43 \%$ of total lignan intake, vegetables $16-30 \%$, and fruit and berries $15-46 \%$.

Beverages were an additional major source of lignans in all countries. The importance of selected food items varied across countries. Rye was the most important contributor to the lignan intake in the Scandinavian countries Denmark and Finland, whereas wheat and 
Table 3. Contribution of aggregated food groups and individual foods to the total lignan intake by gender in five European countries calculated using the Dutch lignan database ${ }^{1}(\%)$

\begin{tabular}{|c|c|c|c|c|c|c|c|c|c|c|}
\hline \multirow[b]{2}{*}{ Food groups } & \multicolumn{2}{|c|}{ Denmark } & \multicolumn{2}{|c|}{ Finland } & \multicolumn{2}{|r|}{ Italy } & \multicolumn{2}{|c|}{ Sweden } & \multicolumn{2}{|c|}{ United Kingdom } \\
\hline & Men (\%) & Women (\%) & Men (\%) & Women (\%) & Men (\%) & Women (\%) & Men (\%) & Women (\%) & Men (\%) & Women (\%) \\
\hline Cereals and grain products & 30 & 27 & 36 & 27 & 17 & 17 & 43 & 26 & 17 & 15 \\
\hline Rye & 17 & 21 & 24 & 17 & 0 & 0 & 0 & 0 & 0 & 0 \\
\hline Wheat & 7 & 4 & 7 & 6 & II & 9 & 24 & 12 & 8 & 6 \\
\hline Other grains & 2 & 2 & $I$ & 1 & I & 2 & 5 & 4 & 8 & 8 \\
\hline Crisp breads & 0 & 0 & 2 & 2 & 3 & 5 & 14 & 10 & 0 & 0 \\
\hline Vegetables & 19 & 20 & 16 & 20 & 26 & 28 & 18 & 30 & 23 & 25 \\
\hline Cabbages & 5 & 5 & 4 & 6 & 5 & 5 & 11 & 19 & 16 & 17 \\
\hline Fruit vegetables & 5 & 6 & 6 & 7 & 15 & 16 & 2 & 3 & 3 & 3 \\
\hline Onion-family vegetables & 5 & 5 & 3 & 3 & 2 & 2 & 2 & 2 & 0 & 0 \\
\hline Fruit and berries & 18 & 25 & 22 & 31 & 42 & 46 & 15 & 23 & 15 & 20 \\
\hline Citrus fruit & I & 2 & 4 & 6 & 4 & 4 & 2 & 3 & 1 & I \\
\hline Malaceous and prunus fruit & I & 2 & 5 & 8 & 36 & 38 & 7 & 10 & 6 & 7 \\
\hline Other fruit & 14 & 19 & 4 & 5 & I & I & 2 & 4 & 5 & 7 \\
\hline Berries & I & 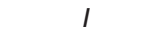 & 5 & 8 & 1 & 2 & 4 & 5 & 2 & 4 \\
\hline Beverages & 21 & 21 & 17 & 17 & 4 & 5 & 19 & 18 & 30 & 32 \\
\hline Coffee & 15 & 12 & 12 & 10 & 3 & 3 & 9 & 9 & II & 10 \\
\hline Tea & 5 & 9 & 5 & 8 & 1 & 2 & 10 & 9 & 19 & 22 \\
\hline Alcohol beverages & II & 5 & 5 & 2 & 9 & 4 & 5 & 2 & 10 & 4 \\
\hline Beers & 6 & I & 4 & I & I & 0 & 4 & I & 8 & 1 \\
\hline Wine & 5 & 4 & I & I & 8 & 3 & I & I & 2 & 3 \\
\hline
\end{tabular}

'Only food groups and food items, which contributed to more than $5 \%$ of the total lignan intake at least in one of the countries, are included. The Dutch food database includes the lignan precursors; secoisolariciresinol (SECO), matairesinol (MAT), lariciresinol (LARI), and pinoresinol (PINO).

other grains were more important in Sweden, Italy, and United Kingdom. Cabbages were important contributors to lignan intake in Sweden and United Kingdom, whereas the group 'fruit vegetables' (e.g. sweet pepper, tomatoes) contributed most to the lignan intake from vegetables in Italy. Malaceous and prunus species fruits (e.g. apricot, peach, pear, and nectarines) were the most important contributors to lignan intake in Italy but were less important contributors in other counties. Tea was the most important contributor to lignan intake in the United Kingdom and in combination with coffee, was a major source to lignan intake in all countries. Among men in Denmark, Italy, and United Kingdom, alcoholic beverages, especially beer and wine contribute to about $10 \%$ of the total lignan intake (Table 3).

\section{Discussion}

The estimated mean lignan intake was approximately fourfold higher when calculations were based on the Dutch lignan database of plant foods including four lignan precursors compared with the calculations using the Finnish lignan database (Fineli ${ }^{\circledR}$ ) that includes two lignan precursors SECO and MAT. The additional contribution to the mean lignan intake from the two additional precursors LARI and PINO was $41-45 \%$ and $32-44 \%$, respectively. These results are in accordance with data from other investigators concluding LARI and PINO to present $>70 \%$ of the total lignan intake (30). Dietary lignan intake further was more strongly associated with plasma enterolignan concentrations when taking all four mammalian lignans into account (31).

Estimations of lignan intake based on the Dutch lignan database showed that the major sources of lignans in Europe are from the food groups: 'cereals and grain products', 'vegetables', 'fruit and berries', and 'beverages'.

In this study, we introduced a relatively simple approach to estimate total lignan intake when food intake data are available. In our approach, average lignan values were applied to food groups that are common in food databases. We used food groups that are known to contribute considerably to the total lignan intake and aggregated them into 42 food groups. The total amount of lignan intake was calculated based on the aggregated amounts of food consumed and the average weighted lignan content of that food group.

In this study, the estimated total lignan intakes based on the Dutch lignan database including four lignan precursors were of similar range as an earlier estimate of 
the lignan intake of $979 \mu \mathrm{g} / \mathrm{day}$ among Dutch men and women aged 19-97 years (20) and very recent estimates among Finnish men (7) and Italian men and women (32). Compared to the total lignan intakes among Dutch men and women, the total lignan intakes were higher in Denmark and Sweden and within similar range in Finland, Italy, and United Kingdom. The high lignan intakes in Denmark and Sweden were mainly due to a higher consumption of rye and wheat products, respectively. In all Scandinavian countries, cereals and grain products are important contributors to lignan intake whereas fruits and berries are main contributors in Italy and beverages (tea, coffee, and beer) are main contributors in the United Kingdom.

The inclusion of the precursors LARI and PINO in the estimated total lignan intake has shown that more food groups contribute to the total lignan intakes than earlier expected. Vegetables, fruit, and berries are important contributors to the total lignan intakes because they have a relatively high content of LARI and PINO (18). When using four lignan precursors, LARI, and PINO were the main contributors to the lignan intake in all five countries. This has been confirmed also in more recent studies $(7,32)$.

In earlier studies, where the lignan intakes was estimated based on MAT and SECO, the major contributor to the lignan intakes was grain products, whereas tea, coffee, nuts, seeds, and selected fruits and vegetables only contributed to a smaller proportion of the intake $(21,22,33)$. The systematically lower values for the SECO + MAT intake values estimated using the Dutch database compared with the values estimated from the Finnish database can be explained mainly by the different analytical methods $(18,24)$.

Some issues need to be discussed in order to fully appreciate the results. First, the 42 food groups were selected because they are important contributors to lignan intake based on former knowledge (24). For each of the 42 food groups, a lignan value was chosen to represent the lignan content of all foods from that food group. The decisions on which these plant lignan values were chosen are provided in Appendix A. The lignan values were calculated from a mean of all foods from a particular food group or from a weighted average. An average was weighted according to the importance of foods consumed from a particular food group and taken into account that certain single foods such as sesame seeds and flaxseeds have a high lignan content. It should be noted that the approach used in this study results in a relatively narrow range of lignan intake. Furthermore, both food databases used in this study have been developed from analyses of locally representative foods in the Netherlands and Finland, respectively. Possible differences in the lignan content of country-specific foods due to differences in types of foods available, preparation of foods, available brands are not taken into account in this study. Finally, the fact that the food consumption data were collected using three different dietary assessment methods, i.e. 7-day food records in Denmark, Italy, and the United Kingdom, a 48-h dietary recall in Finland, and a food frequency questionnaire (FFQ) in Sweden, the results are not directly comparable. This may have led to a larger variation and differences in the estimated lignan intakes across countries. However, the results also reflect different dietary patterns and different food intakes.

In conclusion, we have shown that the total lignan intake was approximately fourfold higher after inclusion of the two new mammalian lignan precursors, LARI and PINO, when compared to estimates based on only SECO and MAT. Furthermore, we have shown that LARI and PINO contributed the majority of the lignan intakes in all five countries. When LARI and PINO were included in the estimation of the total lignan intakes, the major sources of lignans were cereals and grain products, vegetables, fruit, berries, and beverages.

\section{Acknowledgements}

This article is written on behalf of the Phytohealth consortium WP1. Special thanks go to Taina Öhman, Corinna Koebnik, Eva Crammatiki, Alicia Wolk, Yannis Manios, Clarissa Bingham, and Aedin Cassidy for their collaboration to this work. This work was carried out with financial support from the Commission of the European Communities, PHYTOHEALTH QLRT-2001-09453. It does not necessarily reflect its views and in no way anticipates the Commission's future policy in this area.

\section{Conflict of interest and funding}

The authors have not received any funding or benefits from industry or elsewhere to conduct this study.

\section{References}

1. Borriello SP, Setchell KD, Axelson M, Lawson AM. Production and metabolism of lignans by the human faecal flora. J Appl Bacteriol 1985; 58: 37-43.

2. Setchell KD, Lawson AM, Borriello SP, Harkness R, Gordon $\mathrm{H}$, Morgan $\mathrm{DM}$, et al. Lignan formation in man-microbial involvement and possible roles in relation to cancer. Lancet 1981; 2: 4-7.

3. Hausner H, Johnsen NF, Hallund J, Tetens I. A single measurement is inadequate to estimate enterolactone levels in Danish postmenopausal women due to large intraindividual variation. J Nutr 2004; 134: 1197-200.

4. Kuijsten A, Arts IC, Vree TB, Hollman PC. Pharmacokinetics of enterolignans in healthy men and women consuming a single dose of secoisolariciresinol diglucoside. J Nutr 2005; 135: 795-801.

5. Morton MS, Matos-Ferreira A, Abranches-Monteiro L, Correia R, Blacklock N, Chan PS, et al. Measurement and metabolism of isoflavonoids and lignans in the human male. Cancer Lett 1997; 114: 145-51. 
6. Lampe JW, Atkinson C, Hullar MA. Assessing exposure to lignans and their metabolites in humans. J AOAC Int 2006; 89: 1174-81.

7. Nurmi T, Mursu J, Peñalvo JL, Poulsen HE, Voutilainen S. Dietary intake and urinary excretion of lignans in Finnish men. Br J Nutr 2010; 103: 677-85.

8. Van der Schouw YT, Kreijkamp-Kaspers S, Peeters PH, Keinan-Boker L, Rimm EB, Grobbee DE. Prospective study on usual dietary phytoestrogen intake and cardiovascular disease risk in Western women. Circulation 2005; 111: 465-71.

9. Peterson J, Dwyer J, Adlercreutz H, Scalbert A, Jacques P, McCullough ML. Dietary lignans: physiology and potential for cardiovascular disease risk reduction. Nutr Rev 2010; 68: $571-603$.

10. Keinan-Boker L, Der Schouw YT, Grobbee DE, Peeters PH. Dietary phytoestrogens and breast cancer risk. Am J Clin Nutr 2004; 79: 282-8.

11. Hedelin M, Klint A, Chang ET, Bellocco R, Johansson JE, Andersson SO, et al. Dietary phytoestrogen, serum enterolactone and risk of prostate cancer: the cancer prostate Sweden study (Dietary lignans: physiology and potential for cardiovascular disease risk reduction. Nutr Rev 2010; 68: 571-603.

12. Zaineddin AK, Vrieling A, Buck K, Becker S, Linseisen J, Flesch-Janys D, et al. Serum enterolactone and postmenopausal breast cancer risk by estrogen, progesterone and herceptin 2 receptor status. Int J Cancer 2012; 130: 1401-10.

13. Vanharanta M, Voutilainen S, Rissanen TH, Adlercreutz H, Salonen JT. Risk of cardiovascular disease-related and all-cause death according to serum concentrations of enterolactone: Kuopio Ischaemic Heart Disease Risk Factor Study. Arch Intern Med 2003; 163: 1099-104.

14. Guglielmini P, Rubagotti A, Boccardo F. Serum enterolactone levels and mortality outcome in women with early breast cancer: a retrospective cohort study. Breast Cancer Res Treat 2012; 132: $661-8$.

15. Mabrok HB, Klopfleisch R, Ghanem KZ, Clavel T, Blaut M, Loh G. Lignan transformation by gut bacteria lowers tumor burden in a gnotobiotic rat model of breast cancer. Carcinogenesis 2012; 33: 203-8.

16. Abarzua S, Serikawa T, Szewczyk M, Richter DU, Piechulla B, Briese V. Antiproliferative activity of lignans against the breast carcinoma cell lines MCF 7 and BT 20. Arch Gynecol Obstet 201; 285: 1145-51.

17. Lin Y, Yngve A, Lagergren J, Lu Y. Dietary intake of lignans and risk of adenocarcinoma of the esophagus and gastroesophageal junction. Cancer Causes Control 2012; 23: 837-44.

18. Milder IE, Arts IC, van de PB, Venema DP, Hollman PC. Lignan contents of Dutch plant foods: a database including lariciresinol, pinoresinol, secoisolariciresinol and matairesinol. Br J Nutr 2005; 93: 393-402.

19. Heinonen S, Nurmi T, Liukkonen K, Poutanen K, Wahala K, Deyama $T$, et al. In vitro metabolism of plant lignans: new precursors of mammalian lignans enterolactone and enterodiol. J Agric Food Chem 2001; 49: 3178-86.

20. Milder IE, Feskens EJ, Arts IC, Bueno de Mesquita HB, Hollman PC, Kromhout D. Intake of the plant lignans secoisolariciresinol, matairesinol, lariciresinol, and pinoresinol in Dutch men and women. J Nutr 2005; 135: 1202-7.

21. Boker LK, Van der Schouw YT, De Kleijn MJ, Jacques PF, Grobbee DE, Peeters PH. Intake of dietary phytoestrogens by Dutch women. J Nutr 2002; 132: 1319-28.
22. De Kleijn MJ, Van der Schouw YT, Wilson PW, Adlercreutz H, Mazur W, Grobbee DE, et al. Intake of dietary phytoestrogens is low in postmenopausal women in the United States: the Framingham study(1-4). J Nutr 2001; 131: 1826-32.

23. Horn-Ross PL, Barnes S, Lee M, Coward L, Mandel JE, Koo J, et al. Assessing phytoestrogen exposure in epidemiologic studies: development of a database (United States). Cancer Causes Control 2000; 11: 289-98.

24. Valsta LM, Kilkkinen A, Mazur W, Nurmi T, Lampi AM, Ovaskainen ML, et al. Phyto-oestrogen database of foods and average intake in Finland. Br J Nutr 2003; 89(Suppl 1): S31-8.

25. Lyhne N, Groth MV, Christensen T, Fagt S, Biltoft-Jensen A, Hartkopp H, et al. Danskernes kostvaner 2000-2002. hovedresultater (Dietary habits in Denmark 2000-2002). Søborg, Denmark: Danish Institute of Food and Veterinary Research; 2005.

26. Männistö S, Ovaskainen M-L, Valsta L. The national findiet study. Helsinki, Finland: National Public Health Institute; 2002. p. 2003.

27. Turrini A, Saba A, Perrone D, Cialfa E, D'Amicis A. Food consumption patterns in Italy: the INN-CA study 1994-1996. Eur J Clin Nutr 2001; 55: 571-88.

28. Wolk A, Bergstrom R, Hunter D, Willett W, Ljung H, Holmberg L, et al. A prospective study of association of monounsaturated fat and other types of fat with risk of breast cancer. Arch Intern Med 1998; 158: 41-5.

29. Henderson L, Gregory J, Swan G. The National diet and nutrition survey: adults aged 19-64 years. Types and quantities of foods consumed. Report of the office for national statistics and food standard agency, London: TSO. 2002.

30. Zamora-Ros R, Knaze V, Luján-Barroso L, Kuhnle GG, Mulligan AA, Touillaud M, et al. Dietary intakes and food sources of phytoestrogens in the European prospective investigation into cancer and nutrition (EPIC) 24-hour dietary recall cohort. Eur J Clin Nutr 2012; 66: 932-41.

31. Milder IE, Kuijsten A, Arts IC, Feskens EJ, Kampman E, Hollman PC, et al. Relation between plasma enterodiol and enterolactone and dietary intake of lignans in a Dutch endoscopy-based population. J Nutr 2007; 137: 1266-71.

32. Pellegrini N, Valtuena S, Ardigo D, Brighenti F, Franzini L, Del Rio D, et al. Intake of the plant lignans matairesinol, secoisolariciresinol, pinoresinol, and lariciresinol in relation to vascular inflammation and endothelial dysfunction in middle age-elderly men and post-menopausal women living in Northern Italy. Nutr Metab Cardiovasc Dis 2010; 20: 64-71.

33. Linseisen J, Piller R, Hermann S, Chang-Claude J. Dietary phytoestrogen intake and premenopausal breast cancer risk in a German case-control study. Int J Cancer 2004; 110: 284-90.

\footnotetext{
*Inge Tetens

Division of Nutrition

National Food Institute

Technical University of Denmark

Mørkhøj Bygade 19

DK-2860 Søborg, Denmark

Tel: +4535887400

Email: intet@food.dtu.dk
} 
Appendix A. Content of lignan and lignan precursors (SECO, MAT, LARI, PINO) in foods and notes on which the lignan values were chosen

\begin{tabular}{|c|c|c|c|c|c|c|c|c|c|c|}
\hline & \multicolumn{3}{|c|}{ Finnish (Fineli ${ }^{\circledR}$ ) database } & \multirow[b]{2}{*}{ Notes } & \multicolumn{5}{|c|}{ Dutch database } & \multirow[b]{2}{*}{ Notes } \\
\hline & $\begin{array}{l}\text { Total lignan } \\
\text { ug/ / loog }\end{array}$ & $\begin{array}{l}\mathrm{SECO} \\
\mathrm{ug} / \mathrm{I00g}\end{array}$ & $\begin{array}{l}\text { MAT } \\
\mathrm{ug} / 100 \mathrm{~g}\end{array}$ & & $\begin{array}{l}\text { Total lignan } \\
\text { ug/ } / 00 \mathrm{~g}\end{array}$ & $\begin{array}{l}\text { LARI } \\
\text { ug/loog }\end{array}$ & $\begin{array}{l}\text { PINO } \\
\text { ug/100g }\end{array}$ & $\begin{array}{l}\text { SECO } \\
\text { ug/ } / 100 \mathrm{~g}\end{array}$ & $\begin{array}{l}\text { MAT } \\
\text { ug/loog }\end{array}$ & \\
\hline \multicolumn{11}{|c|}{ Cereal and grain products } \\
\hline Rye & 95 & 40 & 55 & Weighted mean (whole grain rye flour) & 458 & 175 & 246 & 23 & 20 & Ryebread x 1.43 \\
\hline Wheat & 25 & 20 & 5 & Weighted mean (wheat flour) & 99 & 60 & 29 & 12 & 0 & Wheatbread $\times 1.43$ \\
\hline Oats and barley & 18 & 13 & 5 & Mean (rolled oats) & 107 & 60 & 29 & 13 & 5 & $\begin{array}{l}\text { Estimate based on FINMAT\&SECO and } \\
\text { the proportions of new precursors }\end{array}$ \\
\hline Rice & 27.4 & 26.4 & 1 & $\begin{array}{l}\text { Mean of foods in the group of rice/rice } \\
\text { containing foods }\end{array}$ & 23.5 & 17.5 & 3.5 & 1.5 & 1 & $\begin{array}{l}\text { Mean of white rice and whole grain } \\
\text { rice }\end{array}$ \\
\hline Pasta and macaroni & 14.5 & 11.6 & 2.9 & Mean of all pastas & 16 & 7 & 5 & 4 & 0 & Cooked pasta \\
\hline Other grains & 16 & 15 & 1 & $\begin{array}{l}\text { Weighted mean (millet, corn, buck- } \\
\text { wheat) }\end{array}$ & 485 & 157 & 313 & 15 & 0 & Mean of 3 müslies \\
\hline Crispbreads (as eaten) & 52.4 & 27.4 & 25 & $\begin{array}{l}\text { Mean of foods in the food group, } \\
\text { MAT-value weighted by rye crisp } \\
\text { bread }\end{array}$ & 412 & 156 & 221 & 21 & 18 & Rye flour $\times 0.9$ \\
\hline Biscuits (as eaten) & 7.2 & 6.8 & 0.4 & Mean of all foods in the group & 18 & 9 & 4 & 5 & 0 & $\begin{array}{l}\text { White flour (taking into account the } \\
\text { moisture) }\end{array}$ \\
\hline \multicolumn{11}{|l|}{ Potatoes } \\
\hline Potato & 3.2 & 2.0 & 1.2 & Weighted mean (potato) & 16 & 10 & 0 & 4 & 2 & $\begin{array}{l}\text { Potatoes (seco and matai estimates } \\
\text { based on Fineli and proportions of new } \\
\text { precursors) }\end{array}$ \\
\hline Potato products & 3.2 & 2.0 & 1.2 & Weighted mean (french fries) & 16 & 10 & 0 & 4 & 2 & Potatoes \\
\hline \multicolumn{11}{|l|}{ Vegetables } \\
\hline $\begin{array}{l}\text { Root vegetables and } \\
\text { tubers }\end{array}$ & 17.5 & 16.6 & 0.9 & $\begin{array}{l}\text { Mean of root vegetables and tubers } \\
\text { (excluding dried carrots) }\end{array}$ & 88 & 31.5 & 9.5 & 47 & 0 & Mean of carrot and red beet \\
\hline Leafy vegetables & 30.5 & 30 & 0.5 & Weighted mean (lettuce) & 57 & 35 & 12.5 & 9.5 & 0 & $\begin{array}{l}\text { Mean of spinach, chicory, endive, } \\
\text { lettuce, Iceberg lettuce }\end{array}$ \\
\hline Cabbages & 30.5 & 30.3 & 0.2 & Mean of the group & 600 & 255 & 335 & 8 & 2 & $\begin{array}{l}\text { Weighted mean (most common } \\
\text { cabbages) }\end{array}$ \\
\hline Fruit vegetables & 5.5 & 5.49 & 0.01 & $\begin{array}{l}\text { Weighted mean (tomato and } \\
\text { cucumber) }\end{array}$ & 132 & 103 & 19 & 10 & 0 & $\begin{array}{l}\text { Mean of sweet pepper, zucchini, } \\
\text { cucumber and tomato }\end{array}$ \\
\hline Onion-family vegetables & 23.8 & 20 & 3.8 & Mean, Seco-value weighted by onion & 287 & 153 & 100 & 34 & 0 & Mean of garlic, leek and onion \\
\hline Canned vegetables & 20 & 20.0 & 0.02 & $\begin{array}{l}\text { Mean of processed vegetables } \\
\text { (excluding pickled pumpkin) }\end{array}$ & 104 & 58.3 & 40.0 & 5.3 & 0 & Mean of corn and pea \\
\hline Edible fungi & 6.0 & 2.4 & 3.7 & Mean of the food group & 0 & 0 & 0 & 0 & 0 & Mushroom \\
\hline
\end{tabular}




\begin{tabular}{|c|c|c|c|c|c|c|c|c|c|c|}
\hline & \multicolumn{3}{|c|}{ Finnish (Fineli ${ }^{\circledR}$ ) database } & \multirow[b]{2}{*}{ Notes } & \multicolumn{5}{|c|}{ Dutch database } & \multirow[b]{2}{*}{ Notes } \\
\hline & $\begin{array}{l}\text { Total lignan } \\
\text { ug/loog }\end{array}$ & $\begin{array}{l}\text { SECO } \\
\mathrm{ug} / \mathrm{I00g}\end{array}$ & $\begin{array}{l}\text { MAT } \\
\mathrm{ug} / \mathrm{l00g}\end{array}$ & & $\begin{array}{l}\text { Total lignan } \\
\text { ug/l00g }\end{array}$ & $\begin{array}{l}\text { LARI } \\
\text { ug/l00g }\end{array}$ & $\begin{array}{l}\text { PINO } \\
\text { ug/lo0g }\end{array}$ & $\begin{array}{l}\text { SECO } \\
\mathrm{ug} / 100 \mathrm{~g}\end{array}$ & $\begin{array}{l}\text { MAT } \\
\mathrm{ug} / \mathrm{lo0g}\end{array}$ & \\
\hline \multicolumn{11}{|l|}{ Pulses and nuts } \\
\hline Pulses & 4.5 & 4.4 & 0.1 & Weighted mean (pea) & 93 & 67 & 14 & 12 & 0 & Estimate according to beans \\
\hline Nuts and seeds & 300 & 299 & 0.9 & Weighted mean (almond, nuts) & 287 & 8.2 & 25.3 & 253 & 0.5 & Mean (nuts) \\
\hline Soy products & 30.5 & 30 & 0.5 & $\begin{array}{l}\text { Estimate according to major soy } \\
\text { containing foods (soy flour, soy beans) }\end{array}$ & 88.9 & 33.8 & 45.5 & 9.6 & 0 & Mean of tofu and soy milk \\
\hline \multicolumn{11}{|l|}{ Fruits } \\
\hline Citrus fruit & 14.6 & 14.6 & 0.02 & Mean of all citrus fruit & 112 & 71 & 33 & 6 & 1.5 & $\begin{array}{l}\text { Mean of grape fruit, mandarine and } \\
\text { orange }\end{array}$ \\
\hline $\begin{array}{l}\text { Malaceous and prunus } \\
\text { species fruits }\end{array}$ & 70.3 & 70 & 0.3 & $\begin{array}{l}\text { Mean of all malaceous and prunus } \\
\text { species fruits }\end{array}$ & 251 & 78 & 157 & 15.5 & 0 & $\begin{array}{l}\text { Mean of apricot, peach, pear, nectarine, } \\
\text { prunes and apple }\end{array}$ \\
\hline Other fruits & 91.8 & 87.3 & 4.4 & Mean of all other fruit & 192 & 76.5 & 50 & 56 & 9.5 & $\begin{array}{l}\text { Mean of raisins, cherries, kiwi, olives, } \\
\text { melons, grapes, pineapple and banana }\end{array}$ \\
\hline Canned fruits & 55.6 & 51.2 & 4.4 & Mean of canned fruit & 20 & 3 & 5 & 7 & 5 & Canned pineapple \\
\hline Berries & 188 & 186 & 2.3 & Mean of all berries & 334 & 117 & 212 & 5 & 0 & Strawberry \\
\hline Juices & 17 & 15 & 2 & Weighted mean (orange juice) & 18.1 & 5.4 & 4.1 & 6.7 & 1.9 & $\begin{array}{l}\text { Mean of grape, tomato, orange and } \\
\text { grape fruit juices }\end{array}$ \\
\hline Juice drinks & 10.3 & 10 & 0.3 & Weighted mean (berry juices) & 35.5 & 3 & 1.5 & 30 & I & $\begin{array}{l}\text { Estimated according to Fineli berry } \\
\text { juices and Milder et al. Berry values }\end{array}$ \\
\hline \multicolumn{11}{|l|}{ Fats } \\
\hline Oils & 0.7 & 0.6 & 0.1 & Mean of oils & 124 & 2.5 & 122 & 0 & 0 & Mean of olive, soy and sunflower oils \\
\hline $\begin{array}{l}\text { Margarine and fat } \\
\text { spread }\end{array}$ & 0.01 & 0.01 & 0 & Mean of margarines & 39 & 7 & 0 & 32 & 0 & Margarine \\
\hline \multicolumn{11}{|l|}{ Beverages } \\
\hline Coffee & 10 & 10 & 0 & $\begin{array}{l}\text { Estimate according to Milder et al. and } \\
\text { Mazur et al. }\end{array}$ & 25 & 11.1 & 0.95 & 12.7 & 0.35 & Mean of three analyzed coffees \\
\hline Tea & 6 & 5 & I & Calculated according to Mazur et al. & 58.4 & 24.8 & 23.2 & 9.00 & 1.6 & Mean of three black and one green teas \\
\hline Soft drinks & 1.3 & 1.3 & 0 & & 0 & 0 & 0 & 0 & 0 & Cola drink \\
\hline \multicolumn{11}{|l|}{ Alcoholic beverages } \\
\hline Beers & I & I & 0 & Estimate according to Milder et al. & 25.5 & 7.6 & 17.4 & 0.5 & 0 & Mean of three lager bears \\
\hline Wines & 62.4 & 56.9 & 5.5 & Mean of all foods in the group & 55.7 & 10.4 & 6.8 & 33.3 & 5.3 & $\begin{array}{l}\text { Mean of three red and three white } \\
\text { wines }\end{array}$ \\
\hline
\end{tabular}


Appendix A (Continued)

\begin{tabular}{|c|c|c|c|c|c|c|c|c|c|c|}
\hline & \multicolumn{3}{|c|}{ Finnish (Fineli ${ }^{\circledR}$ ) database } & \multirow[b]{2}{*}{ Notes } & \multicolumn{5}{|c|}{ Dutch database } & \multirow[b]{2}{*}{ Notes } \\
\hline & $\begin{array}{l}\text { Total lignan } \\
\text { ug/lo0g }\end{array}$ & $\begin{array}{l}\text { SECO } \\
\text { ug/lo0g }\end{array}$ & $\begin{array}{l}\text { MAT } \\
\text { ug/lo0g }\end{array}$ & & $\begin{array}{l}\text { Total lignan } \\
\text { ug/loog }\end{array}$ & $\begin{array}{l}\text { LARI } \\
\text { ug/I00g }\end{array}$ & $\begin{array}{l}\text { PINO } \\
\text { ug/loog }\end{array}$ & $\begin{array}{l}\text { SECO } \\
\text { ug/lo0g }\end{array}$ & $\begin{array}{l}\text { MAT } \\
\text { ug/l00g }\end{array}$ & \\
\hline \multicolumn{11}{|c|}{ Sugar and confectionery } \\
\hline Sugar and syrups & 0 & 0 & 0 & & 0 & 0 & 0 & 0 & 0 & \\
\hline Other sugar products & 5.3 & 5 & 0.3 & $\begin{array}{l}\text { Estimate according to nutspread and } \\
\text { licoridgesauce }\end{array}$ & 0 & 0 & 0 & 0 & 0 & \\
\hline $\begin{array}{l}\text { Non-chocolate } \\
\text { confectionery }\end{array}$ & 19.9 & 19.0 & 0.8 & Mean (excluding halva) & 0 & 0 & 0 & 0 & 0 & \\
\hline Chocolate & 10.1 & 10 & 0.1 & $\begin{array}{l}\text { Weighted mean (milk chocolate and } \\
\text { mean chocolate) }\end{array}$ & 43 & 20 & 23 & 0 & 0 & Dark chocolate \\
\hline \multicolumn{11}{|l|}{ Spices } \\
\hline Dried herbs & 297 & 295 & 1.5 & Mean of all in the food group & 0 & 0 & 0 & 0 & 0 & \\
\hline Dried spices & 0 & 0 & 0 & & 0 & 0 & 0 & 0 & 0 & \\
\hline Condiments & 27.9 & 27.7 & 0.3 & Mean of all in the food group & 0 & 0 & 0 & 0 & 0 & \\
\hline \multicolumn{11}{|l|}{ Manufactured foods } \\
\hline Snacks & 7.6 & 6.2 & 1.4 & Mean of all in the food group & 0 & 0 & 0 & 0 & 0 & \\
\hline Chocolate powder & 32.9 & 32.9 & 0 & From the Fineli database & 60 & 26 & 26 & 8 & 0 & Cocoa powder \\
\hline
\end{tabular}

